


\title{
ANDROID-BASED COLLOIDS SYSTEMS INSTRUCTIONAL MEDIA: MULTIPLICITIES OF PLACE
}

\author{
Yogo D. Prasetyo ${ }^{1)^{*}}$, Resti Yektiyastuti ${ }^{1)}$, Irwanto ${ }^{1)}$, Jaslin Ikhsan ${ }^{2)}$, Kristian H. \\ Sugiyarto ${ }^{2)}$
1) Pendidikan Sains Program Pascasarjana Universitas Negeri Yogyakarta
2) Pendidikan Kimia, FMIPA Universitas Negeri Yogyakarta
*email:prastyogo@gmail.com, jaslinikhsan@gmail.com

\begin{abstract}
This study aims are (1) to develop android-based chemistry instructional media on the colloids system material for high school students and (2) to determine the feasibility of the media developed. This study is research and development that adapted Borg \& Gall and Dick \& Carey models modified into four steps: preliminary study, curriculum study, product development, and evaluation. Media validated by materials experts, media experts, peer reviewers, and high school chemistry teacher, and tested to high school students. Data collection was done by the media assessment instruments. The results showed that (1) chemistry learning media was successfully developed using adobe flash professional cs 6 and can be run on Android devices; (2) the media were appropriate for learning based on assessment of material aspects and media aspects in the Very Good category, and the test results of students also showed that the media in the Very Good category.
\end{abstract}

Key words: instructional media, colloids system, android.

\section{INTRODUCTION}

Global era indirectly requires qualified human resources for the development of the nation. According to UU No. 20 of 2003, qualified human resources is a welleducated human whose faith and fear of God Almighty, noble, healthy, knowledgeable, capable, creative, independent, and become citizens of a democratic and responsible. Cooperation between governments, teachers, and parents of students were required to support the government's efforts in improving the quality of education in Indonesia through effective learning. Learning is the focus of this research is the chemistry learning SMA / MA.

In general, the chemistry learning in high school was done by expository method, demonstration, and practical. Expository method is a way of teaching by giving explanations and examples of questions to the students using teaching materials like text books or modules. This method is not quite optimal to used because students will quickly get bored and students tend to be passive. Demonstrations and practical methods try to involve students actively in learning, but in reality this method is less efficient in the use of time, learning is still a group compared to independent learning, and can be used in 
few subjects/matter. Ineffectiveness election learning method will lead to the motivation and the learning outcomes of students is less than optimal.

Observations and interviews conducted in SMAN 1 Banguntapan in teaching and learning activities in the classroom showed that: (1) transfer of materials that was done by teacher was less varied (only the expository method and using textbooks) and (2) the utilization of instructional media was limited to the presentation slides only and it rarely used teachers in learning. This resulted in less than the maximum learning and impact on learning motivation and cognitive learning outcomes in chemistry also less than the maximum.

The development of Information and Communication Technology (ICT) can be used to make chemistry learning to be interesting and provide a positive impact on motivation and learning outcomes of students (Chuang, 2014, p. 1969). ICT development is supporting the implementation of PP No. 32 of 2013 article 19 paragraph (1) states that the learning activities in the educational unit organized in an interactive, inspiring, fun, challenging, and motivating learners. Instructional media include interactive learning media, e-Learning, or software that can run on mobile devices.

Now, ICT developments have expanded on mobile devices. The development of mobile devices have not been widely used as instructional media yet. Whereas if the mobile device can be used as instructional media, the students can learn anytime and anywhere with an interesting application (Squire, 2009, p. $70 \&$ Meister, 2011, p. 28). Instructional media that developed in this type of device has the potential to help improve cognitive learning outcomes of students (Chuang \& Chen, 2007, p. 27) and the motivation of learners (Hess, 2014, p. 35).

In this study has been developed mobile-based instructionalmedia with operating system of Android. Selection of the Android operating system because the current operating system Android is the operating system's most popular and widely used by the public, especially students. Android development in Indonesia until June 2015 to reach $65.9 \%$. (StatCounter, 2015). Selected material in the media that are developed is colloid chemistry. Chemical materials containing concepts are quite difficult to understand by students because it involves chemical reactions and calculations, and involves abstract concepts and microscopic (Sunyono et al., 2009, p. 9). The key to success in learning chemistry requires a good understanding rather than memorization (Bunce, 2009, p. 674). Colloid chemistry contains reactions and concepts that are abstract and makes students feel bored in studying. This is evidenced by mastery of the material in the colloids system of national examinations in 2013 only reached 76.14\% (Puspendik, 2013). 
This Research and development aims are to developing android-based chemistry instructional media on colloids systems matter and test the feasibility of the media that was developed based on an assessment of materials expert, media experts, peer reviewers and high school chemistry teacher.

\section{RESEARCH METHOD}

This study is Research and Development. Research and development are used to produce and test the effectiveness of these products (Sugiyono, 2010, p. 407). The development model used in this study is adaptation and modification of the development model of Borg and Gall (1983, p. 589) and Dick \& Carey (2005, pp. 6-7). Adaptations and modifications produced the four stages of development. Steps taken in this study, namely (1) a preliminary analysis, (2) analysis of the curriculum, (3) developing media products, and (4) evaluation.

This research was done in 3 high school, namely MA Sunan Pandanaran for individual test, SMAN 1 Godean to small groups test, and SMAN 1 Banguntapan for field test. The research was conducted in May and June 2015. Subjects research consisted of the subject of media validation and subject of test. Subject media validation is 1 expert matter, 1 media expert, 5 peer reviewers, and 5 chemistry teacher of high school. Subject of individual test is 5 students grade XI MA Sunan Pandanaran. Subject of small group test is 10 students of grade XI IPA SMAN 1 Godean. Subject of field test is 31 student of grade XI IPA SMAN 1 Banguntapan.

Collecting data in this study was done by using media assessment tools. This media assessment instrument consisting of (1) sheet media validation, (2) sheet material validation, (3) sheet assessment of peer reviewer and chemistry teacher, and (4) sheet assessment of student. Media assessment instruments was validated by expert judgment. Data that obtained from materials experts, media experts, peer reviewers, chemistry teacher, and students are quantitative data with a scale of 1-5. This data is then analyzed and calculated the average every aspect. Average scores compared with media quality criteria (Widoyoko, 2011, p. 238) as in Table 1.

Table 1. Media Quality Convertion

\begin{tabular}{|c|c|c|}
\hline No & Score Range & Category \\
\hline 1. & $\overline{\mathrm{x}}>\overline{\mathrm{x}} i+1,8 \mathrm{SD}_{\mathrm{i}}$ & Very Good \\
\hline 2. & $\overline{\mathrm{X}} i \hat{i}+0,6 \mathrm{SD}_{\mathrm{i}}<\overline{\mathrm{x}} \leq \overline{\mathrm{X}} i+1,8 \mathrm{SD}_{i}$ & Good \\
\hline 3. & $\overline{\mathrm{x}} i \quad-0,6 \mathrm{SD}_{\mathrm{i}}<\overline{\mathrm{x}} \leq \overline{\mathrm{x}} i+0,6 \mathrm{SD}_{\mathrm{i}}$ & Fair \\
\hline 4. & $\overline{\mathrm{X}} i-1,8 \mathrm{SD}_{\mathrm{i}}<\overline{\mathrm{x}} \leq \overline{\mathrm{X}} i-0,6 \mathrm{SD}_{\mathrm{i}}$ & Less \\
\hline 5. & $\overline{\mathrm{X}} \mathrm{i} \leq \overline{\mathrm{X}}_{i}-1,8 \mathrm{SD}_{\mathrm{i}}$ & Much Less \\
\hline
\end{tabular}




\section{RESULT AND DISCUSSION}

Research and development of android based instructional media was done by adapting the model of development Borg and Gall (1983, p. 589) and Dick \& Carey (2005, pp. 6-7). The model was adapted by grouping into four main steps, namely a preliminary study, curriculum analysis, product development, and product evaluation.

Preliminary study consisted of a literature study and field surveys. Results of the literature study was known that the chemistry matter related to dayly life that contains the abstract concepts of chemistry and chemical reactions and need to be developed in instructional media to facilitate the understanding was colloids systems matter. The results of field surveys that conducted by interview and observation at SMAN 1 Banguntapan showed that learning chemistry was still teacher center. Learning was only done with the expository method, which was an explanation of matter and continued exercises. Learning like that made students easily bored and can result in learning outcomes and motivation to students are not optimal. This was evidenced by the results of the procurement of materials colloids system on a national exam in 2013 only reached $76.14 \%$.

One way to improve learning motivation and learning outcomes of students are using technology-based instructional media (Matsuo et al., 2008, p. 34). Use of technology-based instructional media can also make learning more effective (Riyadi \& Pardjono, 2014 p. 176). Technology that is growing rapidly in Indonesia are android, which reached $65.9 \%$ of the total smartphone operating system in Indonesia at the end of June 2015 (StatCounter, 2015). Therefore, the development of Android-based learning media is very promising.

The development of chemistry instructional media was adapted to high school chemistry curriculum. In accordance with the high school chemistry curriculum colloids system matter is given to high school students of grade XI semester 2 with Competency Standards (SK) 5. Explain properties and systems of colloids and their application in daily life, and Basic Competency (KD) 5.1. Makes a variety of colloids systems with materials in the vicinity and 5.2. Grouping properties of colloids and their application in daily life. Based on this SKKD determined the indicators in the development of instructional media.

Chemistry instructional media product development was done by making a flowchart and storyboard first. The aim of making flowchart was in order to result of media has an easy to use navigation groove in operation, while the making of storyboard aims to make some of the right frame and attractive. Producing the media using Adobe 
Flash Professional CS 6 with Action Script 3. Broadly speaking, the menu listed at the android-based instructional media in colloids system are (1) competence menu, (2) the material menu, (3) the game menu, and (4) the developer profile menu. The main menu display can be seen in Figure 1.

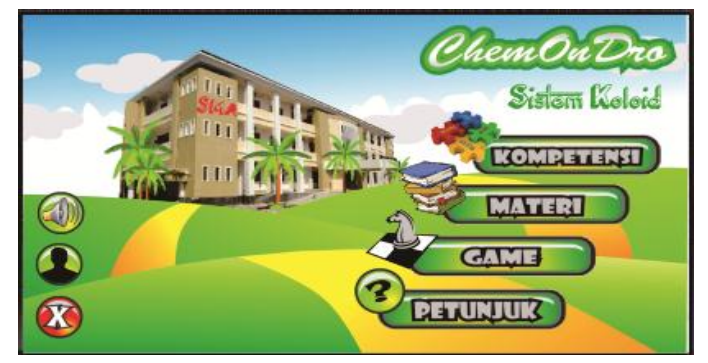

Figure 1. Main Menu Display

The initial product that has been developed further evaluated. Product evaluation is intended to assess or validate the initial product developed media. Validation and assessment carried out by materials expert and media experts. Then proceed assessment by peer reviewer and high school chemistry teacher. Product assessment was done by using the media assessment instruments that have been validated by a validator instruments (expert judgement). Media products that have been validated, then tested the students in the scale of individual, small group, and field test.

\section{Evaluation and Assessment of Materials Aspects}

Evaluation and assessment of the material aspects of the developed instructional media was dine by experts, peer reviewers, and hhigh school chemistry teacher. Aspects assessed include learning aspects and matter aspects. Results of assessment of learning materials can be seen in Table 2 .

Table 2. Results Assessment of Learning Materials Aspects

\begin{tabular}{|c|c|c|c|c|c|c|c|c|c|c|c|c|c|}
\hline \multirow{2}{*}{$\begin{array}{l}\mathbf{N} \\
\mathbf{0}\end{array}$} & \multirow{2}{*}{ Aspects } & \multirow{2}{*}{$\begin{array}{c}\text { Materi } \\
\text { al } \\
\text { Expert }\end{array}$} & \multicolumn{5}{|c|}{ Peer Reviewer } & \multicolumn{5}{|c|}{ Chemistry Teacher } & \multirow{2}{*}{$\begin{array}{l}\text { Max. } \\
\text { Score }\end{array}$} \\
\hline & & & I & II & III & IV & $\mathbf{V}$ & $\mathbf{I}$ & II & III & IV & $\mathbf{V}$ & \\
\hline 1. & Learning & 25 & $\begin{array}{l}2 \\
3\end{array}$ & 22 & 23 & 24 & 21 & 24 & 23 & 24 & 24 & 21 & 25 \\
\hline 2. & Matter & 44 & $\begin{array}{l}3 \\
7 \\
\end{array}$ & 41 & 40 & 42 & 41 & 41 & 42 & 41 & 43 & 39 & 45 \\
\hline & Total & 69 & $\begin{array}{l}6 \\
0 \\
\end{array}$ & 63 & 63 & 66 & 62 & 65 & 65 & 65 & 67 & 60 & 70 \\
\hline & Average & \multicolumn{11}{|c|}{64} & 70 \\
\hline & Category & \multicolumn{11}{|c|}{ Very Good (SB) } & \\
\hline
\end{tabular}

Based on the assessment of materials expert, peer reviewers, and chemistry teacher obtained an average score overall on the materials aspects of learning, namely 64 
(maximum score of 70). The conversion result the average score indicates that the media is included in the value range A with very good category (SB).

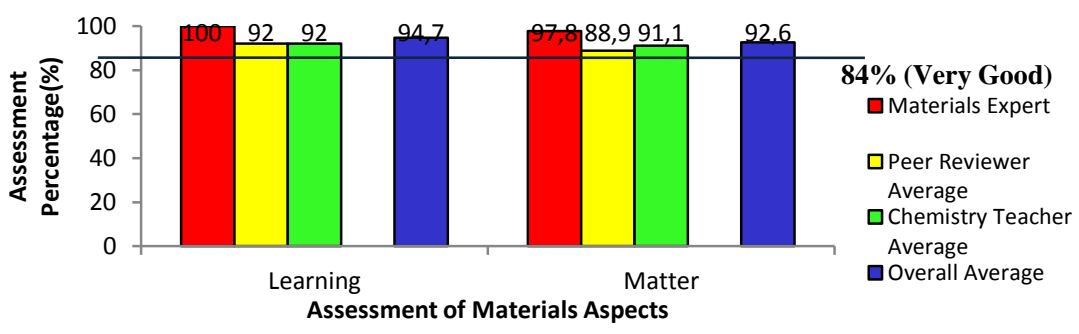

Figure 2. Assessment of Learning Materials Diagram

Thus, the android based chemistry instructional media products on colloids matter was feasible to be tested because it has a very good category of learning materials aspects. The percentage of the final value of the materials aspects on the learning aspect and the matter aspect seen in Figure 2. Percentage of assessment material aspects in Figure 2 showed that the assessment of materials experts, peer reviewers, and chemistry teacher is above $84 \%$, with details learning aspects get average percentage of $94.7 \%$ and a matters aspect get the average percentage of $92.6 \%$. It showed aspects of the material included in the very good category (SB).

Evaluation and assessment material aspects are also in the form of comments and suggestions for revision of the media so that the media produced valid for the material aspects. Comments and suggestions given by the materials expert, peer reviewers, and chemistry teacher. Comments, suggestions and the revised result of media in material aspects described as follows.

The addition explanation dispersed phase and the dispersing medium. This is to facilitate students to understand the difference phases in colloidal systems. Results of the revision can be seen in Figure 3.

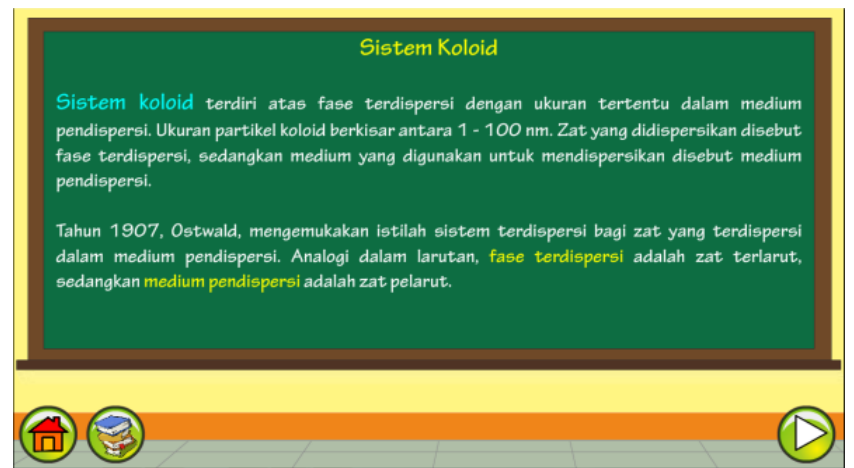

Figure 3. Additioan of Explanation of The Dispersed Phase and dispersant Medium

Revisions in less precise writing. Improvements to the writing error is so that studentss are not confused to understand the material presented in the media. Results of the revision can be seen in Figure 4. 


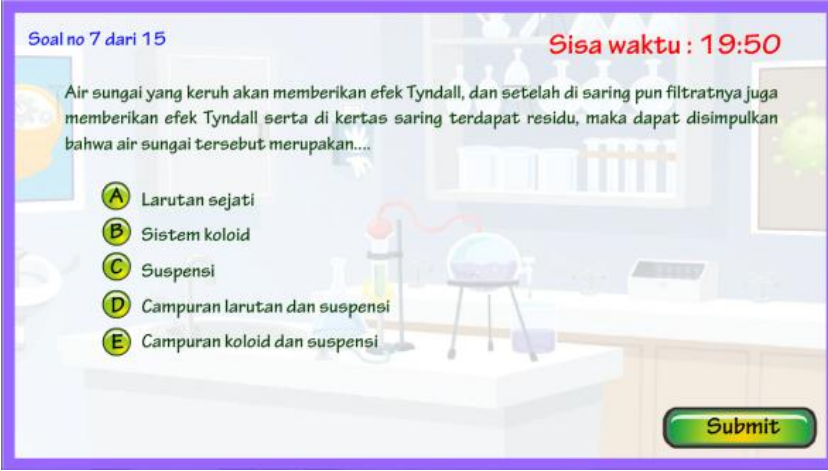

Figure 4. Repair Writing Less Right

The addition of the sample questions related and experienced students. Suggested improvements are intended to make the students can apply the knowledge of chemistry that gained in daily life. Results of the revision can be seen in Figure 5.

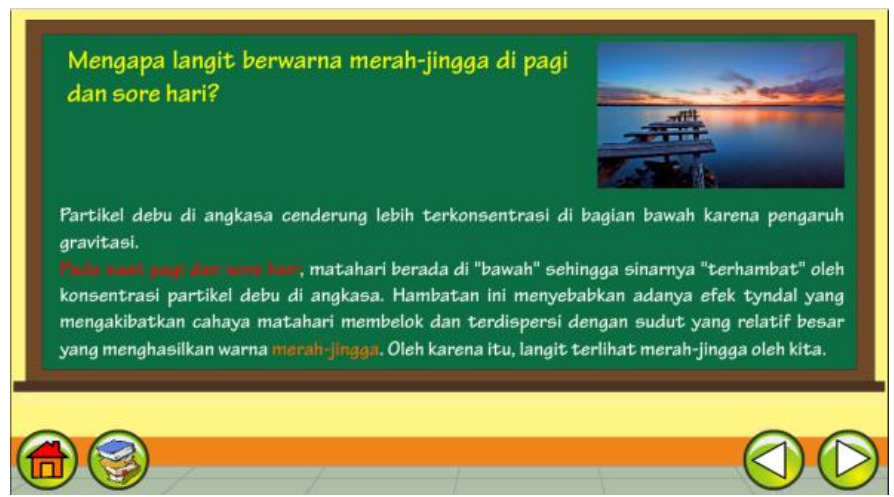

Figure 5. Addition Example Colloidal Events in the Life

\section{Evaluation and Assessment of Media Aspects}

Instructional media assessment was conducted by media experts, peer reviewers, and Chemistry teacher. Aspects considered in this regard include audio-visual aspects and software engineering aspects. Instructional media assessment results can be seen in Table 3.

Table 3. Results Assessment of Instructional Media Aspects

\begin{tabular}{|c|c|c|c|c|c|c|c|c|c|c|c|c|c|}
\hline \multirow{2}{*}{$\begin{array}{l}\mathbf{N} \\
\mathbf{0}\end{array}$} & \multirow[b]{2}{*}{ Aspect } & \multirow{2}{*}{$\begin{array}{c}\text { Media } \\
\text { Exper } \\
\text { t }\end{array}$} & \multicolumn{5}{|c|}{ Peer Reviewer } & \multicolumn{5}{|c|}{ Chemistry Teacher } & \multirow{2}{*}{$\begin{array}{l}\text { Max. } \\
\text { Score }\end{array}$} \\
\hline & & & $\mathbf{I}$ & II & III & IV & $\mathbf{V}$ & $\mathbf{I}$ & II & $\begin{array}{l}\text { II } \\
\text { I }\end{array}$ & IV & $\mathbf{V}$ & \\
\hline 1. & $\begin{array}{l}\text { Audio } \\
\text { Visual }\end{array}$ & 48 & 51 & 50 & 50 & 49 & 47 & 53 & 49 & 49 & 51 & 47 & 55 \\
\hline 2. & $\begin{array}{l}\text { Software } \\
\text { engineerin } \\
\mathrm{g}\end{array}$ & 24 & 22 & 23 & 22 & 24 & 23 & 25 & 24 & 24 & 24 & 21 & 25 \\
\hline & Total & 72 & 73 & 73 & 72 & 73 & 70 & 78 & 73 & 73 & 75 & 68 & 80 \\
\hline & Average & \multicolumn{11}{|c|}{$\mathbf{7 2 , 7 3}$} & 80 \\
\hline & Category & \multicolumn{11}{|c|}{ Very Good (SB) } & \\
\hline
\end{tabular}

The average score of all aspects of instructional media based assessments of media expert, peer reviewers, and chemistry teacher was 72.73 (maximum score of 80). 
These scores are in the range of values A with very good category (SB). These results indicate that the android based chemistry instructional media product on colloids systems was feasible to be tested because it has a very good category of instructional media aspects. The percentage of the final score of Instructional media in the audio visual and software engineering aspects can be seen in Figure 6.

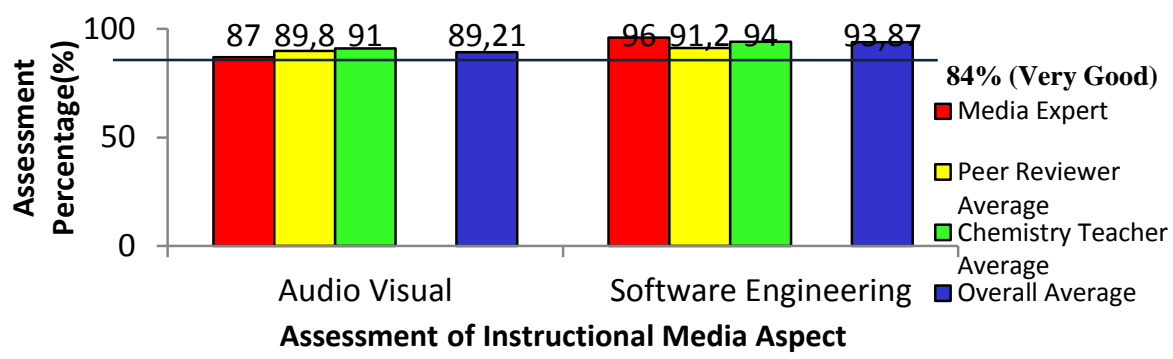

Figure 6. Assessment of Instructional Media Diagram

Figure 6 showed that aspects of the media, both visual audio display and software engineering to get the average percentage of more than $84 \%$, which is $89.21 \%$ and $93.87 \%$. It showed that aspects of media included in the very good (SB) category.

Evaluation and assessment of media aspect also in the form of comments and suggestions for revision of the media. Comments and suggestions aspect of media is intended to produce a display of media interest. Comments, suggestions, and the revised aspects of the media described as follows.

Revised by eliminating the blur effect on the text button. Omission of this blur effect in order to display the button text readable by the user. Results of the revision can be seen in Figure 7.

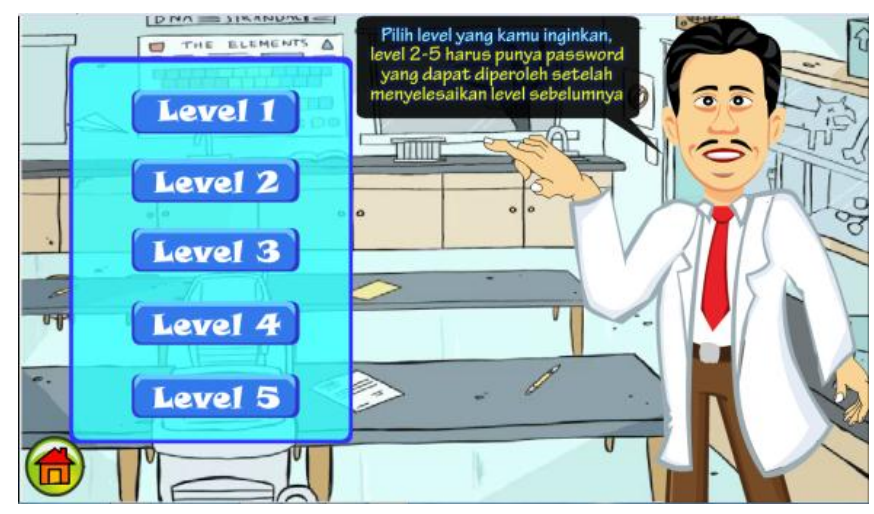

Figure 7. Revised Blur Effect on Text Button

Revision of the blend color with animated buttons are made softer. Animated buttons are made softer so that the colors can be solid and comfortable to be seen. Results of the revision can be seen in Figure 8. 


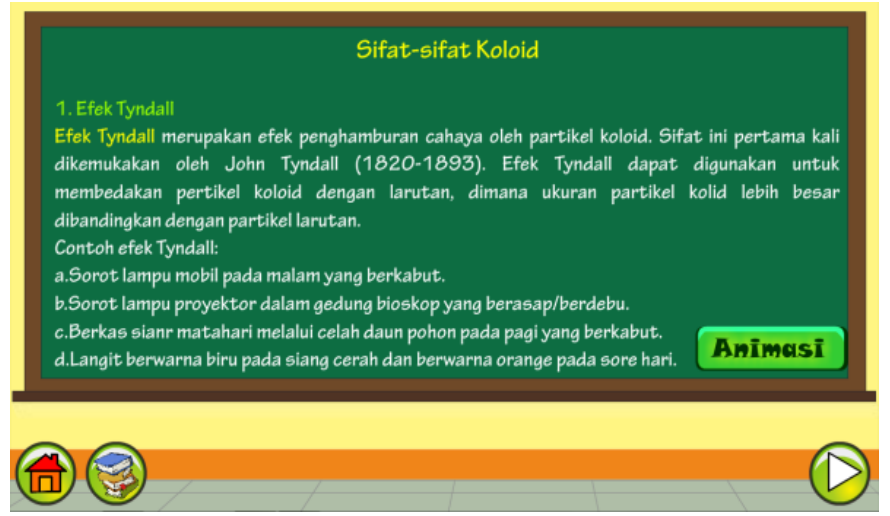

Figure 8. Revised Button Animation

Improvements to the movement of the smoke on the funnel Cottrel animation. Animated movement of smoke still broken is made more smooth and comfortable to be seen. Results of the revision can be seen in Figure 9.

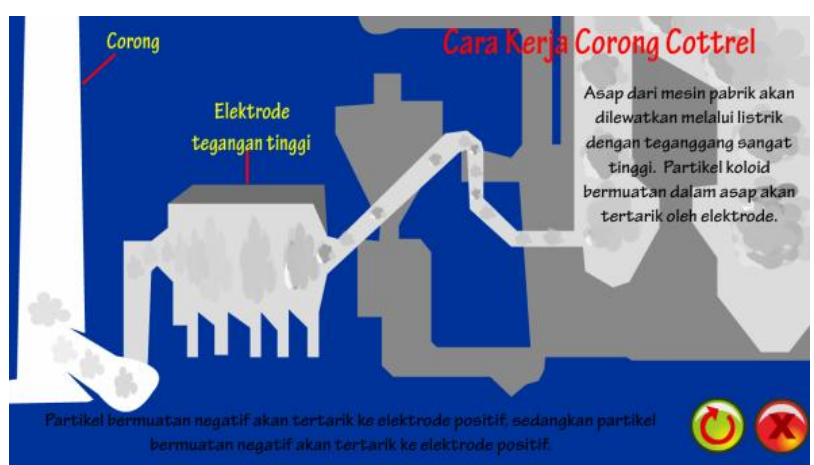

Figure 9. Revised Animation Smoke

Revisions to the addition of media usage instructions at every level of the game. Addition of instructions every level of the game is to allow users in the use of instructional media. Results of the revision can be seen in Figure 10.

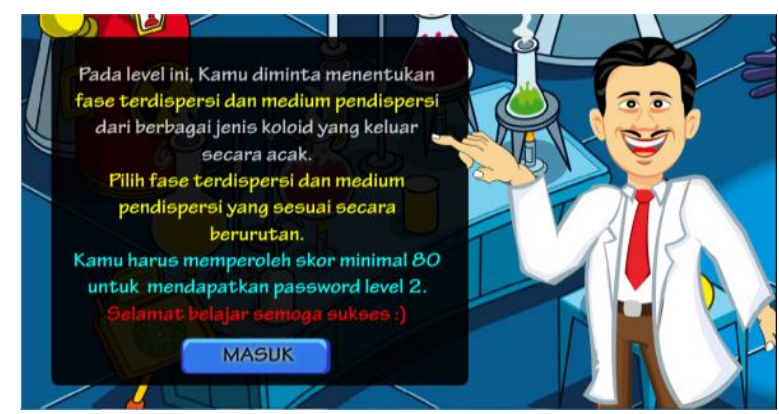

Figure 10. Adding Instructions Every Level

\section{Evaluation and Assessment Testing Products}

Evaluation and assessment of media products in the test phase includes three activities, namely individual test, small groups test, and field test. Aspects assessed include learning and matter aspects and display and operational aspects of the media. Results of the assessment at this stage of the trial/test to students can be seen in Table 4 . 
Table 4. Assessment Media Result of Test Phase

\begin{tabular}{|c|c|c|c|c|c|}
\hline \multirow{2}{*}{ No } & \multirow{2}{*}{ Aspect } & \multicolumn{3}{|c|}{ Average of Test } & \multirow{2}{*}{ Max Score } \\
\hline & & Individual & Small Group & Field & \\
\hline 1. & $\begin{array}{l}\text { Learning and } \\
\text { Matter }\end{array}$ & 23,4 & 22,9 & 22,094 & 25 \\
\hline 2. & $\begin{array}{l}\text { Display and } \\
\text { Operational }\end{array}$ & 45,2 & 44 & 42,2 & 50 \\
\hline & Total & 68.6 & 66.9 & 64.294 & 75 \\
\hline & Average & & 66,598 & & 75 \\
\hline & Category & & Very Good (SB & & \\
\hline
\end{tabular}

Media assessment results in the test phase android based instructional media obtained an overall average score was 66.598 (maximum of 75). These results indicate that the android based chemistry instructional media are in the score range of A with very good category (SB). Thus, based on the test results of android based chemistry instructional media products are feasible for use as included in the very good category (SB).

The percentage of test assessment results and material based on learning and matter aspects and display and operational aspects can be seen in Figure 12.

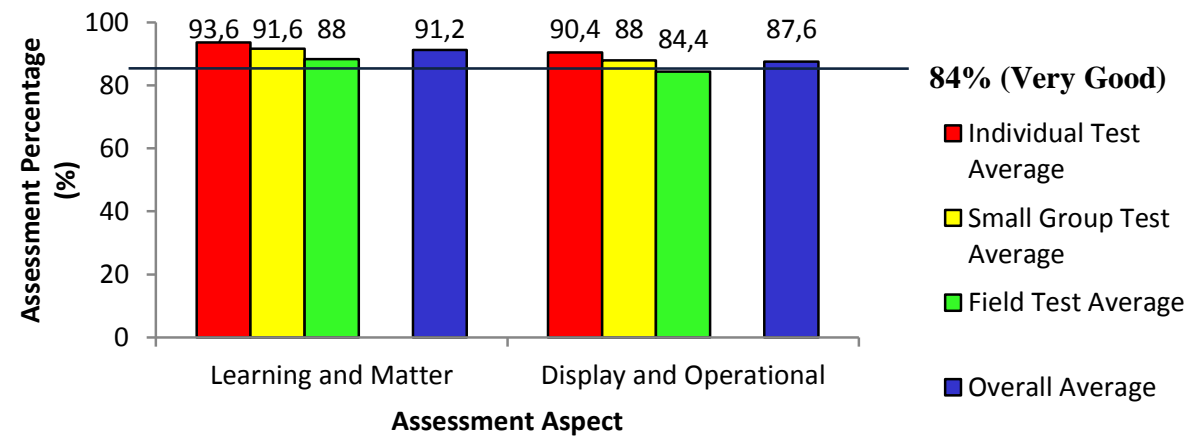

Figure 12. Media Assessment on Test Phase Diagram

Based on Figure 12 it can be seen that the test media to the students obtained a percentage of more than $84 \%$ both in individual test, small group test, and field test. This showed that the android-based instructional media have very good (SB) quality based on the results of the test media.

\section{Characteristic of Final Product}

Android-based chemistry instructional media on colloids system that has been developed has characteristics, namely (1) the relevant learning material, meaning that the material presented in the instructional media in accordance with high school chemistry curriculum and according to the characteristics and needs of the students in high school. The relevance of these media is essential in making instructional media (Mulyanta, 2009, pp. 3-4), (2) clear and interesting visualization, meaning images, animation, and layout 
was made clear in the media and makes appeal students in use. This is in accordance with the submitted Suki \& Suki (2007, p. 355) that the mobile media learning should have a clear picture and good to facilitate students in understanding the material and makes the appeal in the use of media, (3) flexible, meaning that media can used anywhere and anytime. This is consistent with the results of research Chuang \& Cheng (2007, p. 27), that the digital learning media can facilitate students in learning anytime and anywhere and can increase motivation and memory students because it can be used repeatedly. Squire (2009, p. 70) also states that mobile learning media can be used students without being tied to time and place, and (4) vary of evaluation, means android based instructional media developed has many types of evaluation that can be used students to hone their ability in absorbing material colloids system. Chemical characteristics of the android-based instructional media can support students in improving learning outcomes and motivation to learn. It is as it was delivered by Matsuo et al. (2008, p. 34) and Sakat et al. (2012, p. 874) that use the technology-based media can enhance learning motivation and make learning more attractive, interesting, and fun. The same thing also delivered by Anggraeni (2013, p. 11) that the use of Android-based learning media can increase the motivation of students. Jabbour $(2013$, p. 1) in the results of the research also revealed that the use of mobile learning can impact on improving learner outcomes.

\section{CONCLUSION AND SUGGESTION}

Based on the research results can be concluded: (1) android based chemistry instructional media on colloids systems was successfully developed using adobe flash professional CS 6 and can be run on android devices (2) media that have been developed in terms of assessment material aspects and media aspects included in the very good category, and the test results to students included in the very good category, so it feasible to use in learning.

Product of android based chemistry instructional media on colloids systems matter has been assessed for feasibility, so it is advisable chemistry teacher and students can use it as an alternative media of learning. In addition it is necessary to develop a similar media with another subject matter to complement instructional media in each of the subject matter and also need to be developed in multiple operating systems, so the chemistry instructional media can be used on other operation system of devices.

\section{ACKNOWLEDGMENT}

This work received partial support from Hibah Penelitian Pascasarjana DIKTI. This reserach was done by cooperate with SMAN 1 Banguntapan, SMAN 1 Godean, SMAN 1 Kalasan, MA Sunan Pandanaran, MAN Wonokromo. This work would never 
have been completed without the encouragement and counsel of Jaslin Ikhsan, Ph.D and

Prof. K.H. Sugiyarto, Ph.D

\section{REFERENCES}

Anggraeni, R \& Kustijono, R. (2013). Pengembangan Media Animasi Fisika Pada Materi Cahaya Dengan Aplikasi Flash Berbasis Android. Jurnal Pendidikan Fisika dan Aplikasinya (JPFA), 3 (1), 11-18.

Borg, W. R., \& Gall, M. D. (1983). Education Research. New York: Longman.

Bunce, D. M. (2009). Teaching is More Than Lecturing and Learning is More Than Memorizing. Journal of Chemical Education, 86 (6), 674-680.

Chuang, T. Y., \& Chen, W. F. (2007). Effect of Digital Games on Children's Cognitive Achievement. Journal of Multimedia, 2 (5), 27-30.

Chuang, Y. T. (2014). Increasing Learning Motivation and Student Engagement through the Technology-Supported Learning Environment. Creative Education, 5, 19691978.

Dick, W. \& Carey, L. (2005). The Systematic Design Instruction. Boston: Pearson.

Hess, S. (2014). Digital Media and Student Learning: Impact of Electronic Books on Motivation and Achievement. New England Reading Associatiion Journal, 49 (2), 35-39.

Jabbour, K. K. (2014). An Analysis of the Effect of Mobile Learning on Lebanse Higher Education. Informatics in Education, 13 (1), 1-15.

Matsuo, K., Barolli, L., Xhafa, F., Koyama, A., \& Durresi, A. (2008). New Function for Stimulating Learners' Motivation in a Web-Based e-Learning System. Journal of Distance Education Technologies, 6 (4), 34-49.

Meister, J. (2011). 2011: The Year of the Media Tablet As a Learning Tool. Proquest, 65 (4), 28-31.

Mulyanta. (2009). Tutorial membangun Media Interaktif Media Pembelajaran. Yogyakarta: Universitas Atma jaya.

Puspendik. (2013). Panduan Pemanfaatan Hasil Ujian Nasional Tahun Pelajaran 2012/2013 untuk Perbaikan Mutu Pendidikan. Jakarta: BSNP.

Riyadi, S., \& Pardjono, P. (2014). Pengembangan Multimedia Pembelajaran Matematika Berbasis Komputer untuk Kelas VIII SMP. Jurnal Inovasi Teknologi Pendidikan, 1(2). Retrieved fromhttp://journal.uny.ac.id/index.php/jitp/article/view/2527

Sakat, A. A., Mohd Zin, M. Z., Muhamad, R., Ahmad, A., Ahmad, N. A., \& Kamo, M. A. (2012). Educational Technology Media Method in Teaching and Learning Progress. American Journal of Applied Sciences, 9 (6), 874-888.

Squire, K. (2009). Mobile media learning: multiplicities of place. On the Horizon, 17 (1), 70-80.

StatCounter. (2015, Juli 2). Top 8 Mobile \& Tablet Operating Systems in Indonesia from June 2013 to June 2015. Retrieved Juli 2, 2015, from http://gs.statcounter.com/\#mobile+tablet-os-ID-monthly-201306-201506

Sugiyono. (2010). Metode Penelitian Pendidikan Pendekatan Kuantitatif, Kualitatif, dan $R \& D$. Bandung: Alfabeta.

Suki, N. M., \& Suki, N. M. (2007). Mobile Phone Usage for M-Learning: Comparing Heavy and Light Mobile Phone Users. Campus-Wide Information Systems, 24 (5), 355-365.

Sunyono, I. W. W., Susanto, E., \& Suyadi, G. (2009). Identifikasi Masalah Kesulitan Dalam Pembelajaran Kimia SMA Kelas X di Profinsi Lampung. Jurnal Pendidikan MIPA, 10 (2), 9-18. 